\title{
The Role of Education and Income in Poverty Alleviation:
}

\author{
A Cross-Country Analysis
}

\section{Pervez Zamurrad Janjua* and Usman Ahmed Kamal ${ }^{* *}$}

\begin{abstract}
The existing literature on education and poverty considers mostly primary data from an income point of view. However, the benefits of education vary from a direct income effect to positive externalities, which can help reduce poverty. This paper uses panel data for 40 developing countries for the period 1999 to 2007, and estimates coefficients by applying the random effect generalized least squares (GLS) technique. The study concludes, first, that income growth plays a moderately positive role in alleviating poverty, but that income distribution does not play a key role in poverty alleviation in the sample overall. Second, it concludes that education is the most significant contributor to poverty alleviation.
\end{abstract}

Keywords: Education, income, income distribution, poverty alleviation, GLS, Pakistan.

JEL Classification: I30, I32.

\section{Introduction}

There has been ongoing debate on poverty for the last few decades. Why does the poverty exist throughout the world? What is happening to the world's poor? How can poverty be reduced? In particular, when we talk about globalization, economic growth, and living standards, we also talk about poverty. People living in poverty are unable to meet their basic needs, such as essential nourishment, basic health, and education. An expansion in earnings leads to a better nutrition plan, improved health, and better education. The recent focus on poverty by global bodies such as the World Bank and United Nations indicates the grimness of this issue. The Millennium Development Goals were put forward in September 2000 by the World Bank and United

\footnotetext{
* Foreign Professor at the International Institute of Islamic Economics, International Islamic University, Islamabad, Pakistan.

** MPhil student at the International Institute of Islamic Economics, International Islamic University, Islamabad, Pakistan.
} 
Nations in an attempt to halve extreme poverty by 2015 from its level in 1990.

The World Bank's latest available estimates of poverty for 2005 reveal that about $25 \%$ of the world's population is extremely poor: that is, one in every four people is poor. Anti-poverty programs claim to have effectively resulted in a decline in the poverty level, bringing poverty down to half its level in 1990. Figure-1 below illustrates changes in the incidence of poverty between 1981 and 2005.

Figure-1: Incidence of poverty (116 countries calculated at US\$1.25 per day/person)

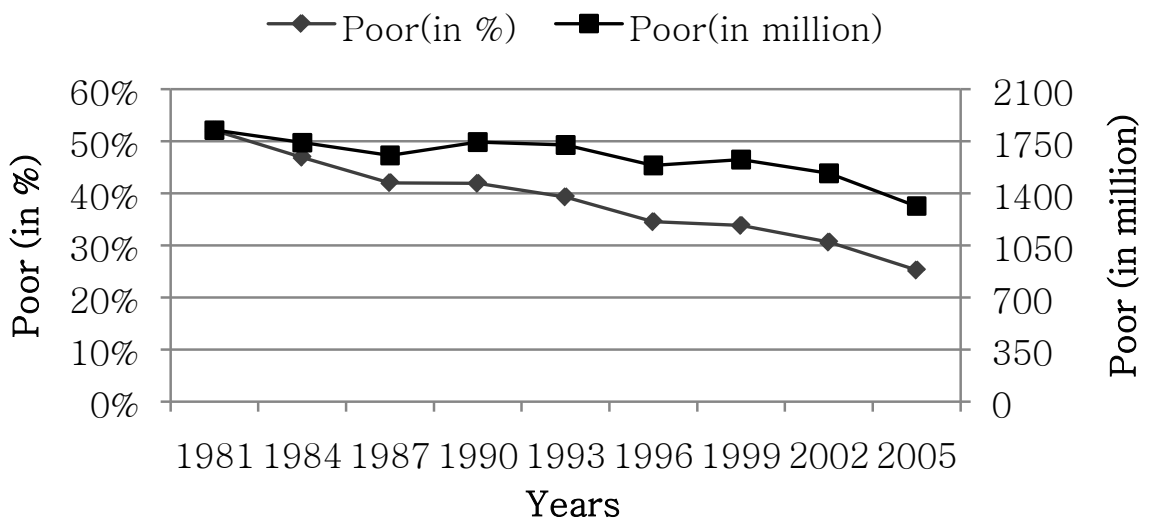

Source: "PovcalNet", available on the World Bank web site http:/ /www.worldbank.org

In a period of 24 years, poverty declined to 26 percent (by more than half its level in 1981). However, the actual numbers (instead of percentages) reveal that the rate of change has been sluggish. According to World Bank estimates for 116 countries in 1981, the total population of these countries was approximately 3,504 million, which increased to 5,205 million by 2005 . In terms of these figures, the number of people living in poverty was 1,826 million in 1981 and 1,315 million in 2005, which shows that the number of people living in poverty actually fell by 511 million during this period. So, in reality, the decline in poverty is lower than perceived since 1981.

\subsection{Statement of the Problem}

The issue of poverty gives rise to two basic questions. First, why are people poor? Second, how can the poor escape poverty? Finding an appropriate solution to poverty requires determining its causes. Does the growth rate of per capita income influence poverty? Does a low income 
level lead to poverty? Does the income gap between rich and poor create poverty? Does the difference in earning ability between low- and highincome groups cause poverty? Here, an empirical investigation of plausible poverty determinants becomes indispensable.

Many research analyses highlight the significance of income and income inequality as determinants of poverty. A significant amount of work on poverty has been done using income-based determinants, but poverty is not confined to income or income differentials. Different studies discuss income variables, income growth, and income inequality as possible determinants of poverty, and provide mixed evidence. If we assume on the basis of these findings that income variables do not adequately explain poverty alleviation, then we need to explore other possible determinants of poverty, e.g., lack of education, among others. ${ }^{1}$

\subsection{Objectives and Hypotheses}

In assuming that the poor do not want to remain poor and that others can play a role in helping them escape the vicious cycle of poverty, international organizations focus predominantly on income growth to alleviate poverty. Policymakers at the national level often aim for higher per capita income or reduction of income inequality to achieve the objective of poverty alleviation. The education level of an earning household member is an active factor in poverty risk (the risk of becoming poor), not only for himself/herself but also for his/her family. Since education can affect a person's earnings positively, estimates of the effect of education on poverty levels are useful for anti-poverty policy perspectives. The primary intention of this paper is to explore whether the formally educated population of a country has a considerable impact on the magnitude of poverty along with other variables such as per capita income growth and income inequality.

The World Bank classifies countries on the basis of income into four groups: low income, lower middle income, upper middle income, and high income. Here, we will focus on the first three because absolute poverty is not a major issue for high-income countries. We will randomly select a set of 40 countries from a population comprising those countries that fulfill our data requirements. We will then estimate an econometric model to test the following hypotheses:

\footnotetext{
${ }^{1}$ Asset distribution can also affect poverty. However, due to the nonavailability of data and estimation issues, we have excluded it from our investigation.
} 
1. Does the number of formally educated people have a significant impact on the poverty extent of a country?

2. What contributes more to poverty reduction: education, per capita income growth, or income inequality?

3. Do all three variables behave similarly in different income groups of countries?

\subsection{Significance of the Study}

This study is based on theoretical as well as empirical observations and is distinctive because it investigates education as an additional determinant of poverty in contrast to conventional income-based determinants. Absolute poverty is a fundamental barrier to development, particularly for developing countries, which spend large amounts of funds in coordination with international organizations with the aim of poverty alleviation. A cheaper and more effective policy for poverty alleviation is crucial as public resources are not unlimited. Ascertaining the strength of different determinants of poverty can help establish appropriate policy recommendations.

Obviously, a world with a large number of poor people is neither socially nor economically acceptable. The central motivation to work on this issue was the yet unresolved poverty problem of Pakistan. A prominent view in the literature on economic development is that the poor have certain common characteristics that force them to stay poor: this is usually known as the "poverty trap." Therefore, useful results can be produced by analyzing the collective datasets of different countries to ascertain the causality of poverty. For Pakistan, the results of other countries' cumulative experience in recent years could provide a better path to move on.

\section{Literature Review}

The vast literature on poverty can be classified into theoretical and empirical approaches. Theoretical approaches focus mostly on the types of poverty or different social aspects of poverty. The empirical literature investigates evidence of the relationship between underlying variables based on observed statistics. The literature can also be divided on the basis of micro- and macro-level approaches.

Ellis (1984) takes a theoretical approach to describing different types of poverty. Here, the nature of poverty is examined in relation to a 
model of causes affecting the welfare of a community, suggesting that it possible to operationally distinguish among four major dimensions of poverty: economic, social, political, and legal. The study also discusses further aspects of poverty, stating that the classification of poverty into different types can help in understanding the problems faced by the community.

Ravallion (2001) describes the techniques used by the World Bank to measure poverty. The selected common poverty line (US\$1 a day) typically prevails in low-income countries. This poverty line is converted into the local currency for consumption surveys by using purchasing power parity (PPP) exchange rates. Ravallion (2003) explains how different measures used for poverty or any other variable can lead to dissimilar results; if the approaches used are different, then their results cannot be considered legitimate.

Squire (1993) reviews efforts to reduce poverty in the developing world. The study uses country- and regional-level figures for poverty headcount, growth, and health measures to compare these efforts, concluding that (i) economic growth should be encouraged to induce the productive use of labor so that the poor can earn to escape poverty, (ii) public spending is an important source of improving health and educational attainment among the poor, and (iii) the provision of subsidized social services is better than direct cash transfers. The study does not use an estimation model to observe the effects of social indicators such as education and health on poverty.

\subsection{Income and Poverty}

Using survey data for 67 developing and transitional economies over 1981-94, Ravallion and Chen (1997) ${ }^{2}$ show the type of correlation between growth of average living standards and poverty. They find a strong association between the rate of growth in average living standards and the rate at which absolute poverty falls: poverty almost always falls with a growth in average living standards and rises with a contraction. They also examine the relationship between living standards and income distribution and find that higher growth rates in average living standards do not tend to worsen the income distribution.

\footnotetext{
${ }^{2}$ Ravallion and Chen use income or expenditure as a welfare indicator, where income denotes household income per person and expenditure denotes household expenditure per person.
} 
Ravallion and Datt (1996) decompose growth on the basis of sector output to determine the impact of the growth of different sectors on poverty. They show that the growth of the primary and tertiary sectors has contributed to a reduction in both urban and rural poverty, while the secondary sector has not delivered much to India's poor. They suggest fostering the growth of the primary and tertiary sectors to reduce poverty. However, they do not point to the alternative of enabling the poor to gain from the secondary sector by providing them with the skills and education that the sector requires, i.e., more skilled labor than the primary sector.

\subsection{Income Inequality and Poverty}

Besley and Burgess (2003) discuss global poverty trends, showing where the world's poor are located and how their numbers have changed over time. They also discuss the relationship between poverty, per capita income, and income inequality using regression estimation. Their findings confirm that increases in income per capita are associated with reductions in poverty. The study's outcome also illustrates the positive and significant association between income inequality and poverty.

Bénabou (2003) examines the interactions between income inequality, technological choice, and redistributive policies or institutions, showing that "a skill-biased technical change can potentially lead to the unraveling of the welfare state. When technological or organizational form is endogenous, firms respond to greater human capital heterogeneity with more flexible technologies, further exacerbating income inequality." This implies that human capital heterogeneity can result in income inequality via the wage inequality mechanism. In this scenario, the existence of social contracts such as educational assistance for the poor could help greatly in reducing wage inequality.

\subsection{Education and Poverty}

Shirazi (1994) investigates the incidence of poverty and socioeconomic profiles of the poor in Pakistan. He also explores the possibility of poverty alleviation through infaq using zakah and ushr collection. The study reveals that, in Pakistan, "the proportion of poor households having highly educated heads is extremely low [and the] majority of the educated heads of the poor household fall in the primary or below matriculation category of education." He also demonstrates how 
"as the educational level of the head of the household increases the probability of that household being poor decreases."

Using data from the China Health and Nutrition Survey, Goh, Luo, and Zhu (2009) investigate the effect of income growth on poverty for the period 1989-2004 in eight provinces of China. They show that growth in income affects poverty negatively. In their study, income was found to grow for all segments of the population and, as a result, poverty incidence fell but the growth was uneven by region. Another finding was that education played an increasingly important role in household income determination for both urban and rural areas. Income gaps have increased between households with more and less human capital endowment.

Fafchamps and Quisumbing (1999) determine whether human capital affects the productivity and labor allocation of rural households in four districts of Pakistan. Using survey data collected by the International Food Policy Research Institute, the study's results show that "education raises off-farm productivity and induces rural Pakistani households to shift labor resources from farm to off-farm activities. This effect is strong, robust, and demonstrated via both the direct and indirect methods."

Maitra (2000) finds that the gap between the educated and noneducated increased in South Africa during the observed period due to differences in earning capacity. The study concludes that a household whose head has attained more than secondary school-level education performs significantly better than all other households.

Gundlach, Pablo, and Weisert (2002) study the relationship between education and income inequalities. According to their findings, "Education is not distribution neutral. Education seems to improve the income distribution and thus may allow the poor to benefit from growth to a greater extent. Accordingly, a focus of economic policies on education in order to reduce poverty and to speed up development appears to be justified."

Datt and Ravallion (1998) study a selected set of Indian states and show that "differences in trend rates of poverty reduction among states are attributed to differing growth rates of farm yield per acre and differing initial conditions; states starting with better infrastructure and human resources saw significantly higher long-term rates of poverty reduction." Some part of this better farm yield can also be considered an externality of education, as argued by Orazem, Glewwe, and Patrinos (2007), who show 
that the impact of education on earnings and thus on poverty works mostly through the labor market. However, education can also add to productivity in other areas, such as peasant farming.

Mitch (2005) attempts to compare a number of existing studies on the relationship between education (schooling) and economic growth from a historical perspective. He finds that schooling may or may not have caused economic growth empirically. Rates of schooling and rates of economic growth have been observed to move in the same and opposite directions over the last three centuries. According to this analysis, human capital development, physical capital accumulation, structural changes in the economy, and foreign trade do play key roles in economic growth.

Barro (1996) uses panel data for 100 countries to test certain empirical theories related to growth. He uses the 3SLS technique for different constructed equations with different instrumental variables in each. His results show that, for a given level of per capita gross domestic product (GDP), the growth rate is positively affected by a higher initial level of schooling. Krueger and Lindahl (2001) attempt to reconcile the micro-econometric and empirical macro-literature on the effect of schooling on income and GDP. They show that the micro-level positive relationship between education and income is also true at a cross-country level.

Despite the potential difficulties (Mitch, 2005) in quantifying the real contribution of education to economic growth, education has always been considered a dominant tool for reducing poverty and inequality through productivity enhancement, which is also a key factor in sustainable economic growth. Easterly and Levine (2000) show that productivity growth explains most of the economic growth of developed countries while capital accumulation explains only a small part. Many countries continue to accumulate capital even while their economies shrink. Although total factor productivity relates to labor, land, and capital, the role of labor productivity is more important than all other factors of production. Education and skill promote labor productivity and, consequently, labor productivity positively influences the productivity of other factors of production.

In the literature, education and poverty exist in both directions, with low education being a cause and an effect of poverty. Estimating causality is always important because if we know the robustness of cause toward effect, then we can address the problem effectively. Poverty is strongly correlated with a range of family background variables, 
including parental education, which also influences children's educational outcomes (Berg, 2008) and at the same time, poverty is just one of many family background factors that limit learning. The Chronic Poverty Research Centre (2005) refers to evidence showing that formal education is strongly associated with the decreased possibility of chronic poverty. It also indicates that the level of schooling at which this might happen can vary between countries. The Chronic Poverty Research Centre (2008) shows that low education is a key factor in keeping people poor over decades or lifecycles. Our concern here is absolute poverty so we will not discuss the literature on chronic poverty as it requires addressing the vast area of nonquantitative aspects of poverty and other social variables.

The absolute poor in developing countries usually have low or even no education. According to the United Nations Educational, Scientific and Cultural Organization (UNESCO) (2007), the children most likely to be out of school or to drop out live in rural areas and come from the poorest households. The underlying aim of the Early Childhood Care and Education program was to provide a strong foundation in early childhood to escape from poverty in the future. Geda, Jong, Kimenyi, and Mwabu (2005) explore the determinants of poverty in Kenya by using household data. They reveal that, among all the variables "in all models, the most important determinant of poverty status is the level of education. Lack of education is a factor that accounts for a higher probability of being poor." Londoño (1996) suggests that inadequate education is the most important factor holding back Latin American economic growth and thus sustaining high levels of inequality and poverty. He concludes that improved education can bring about a large and relatively quick reduction in poverty due to its effect on individuals' earnings and growth.

Harper, Marcus, and Moore (2003) provide a comprehensive review of the literature on poverty reduction. Their discussion covers a number of key social processes that affect poverty. They also highlight the significance of education as a means of poverty reduction, and argue that a good-quality formal education widens horizons and increases future employment opportunities. They conclude that education can facilitate upward economic and social mobility, a better-paying and safer job, and general wellbeing. This conclusion confirms the importance of education in breaking different aspects of the poverty cycle, ranging from individual earning to parental and family effects. 
Berg (2008) says: "Throughout the world it has been found that the probability of finding employment rises with higher levels of education, and that earnings are higher for people with higher levels of education." According to the study, "This connection between education and poverty works through three mechanisms. Firstly, more educated people earn more. Secondly, more (and especially better quality) education improves economic growth and thereby economic opportunities and incomes. Thirdly, education brings wider social benefits that improve economic development and especially the situation of the poor, such as lower fertility, improved health care of children and greater participation of women in the labor force." These findings support the view that the benefits (direct and indirect) of education result in changes in people's behavior and this behavioral change inevitably has an impact on poverty alleviation.

Figure 2: Impact of Education on Poverty Alleviation

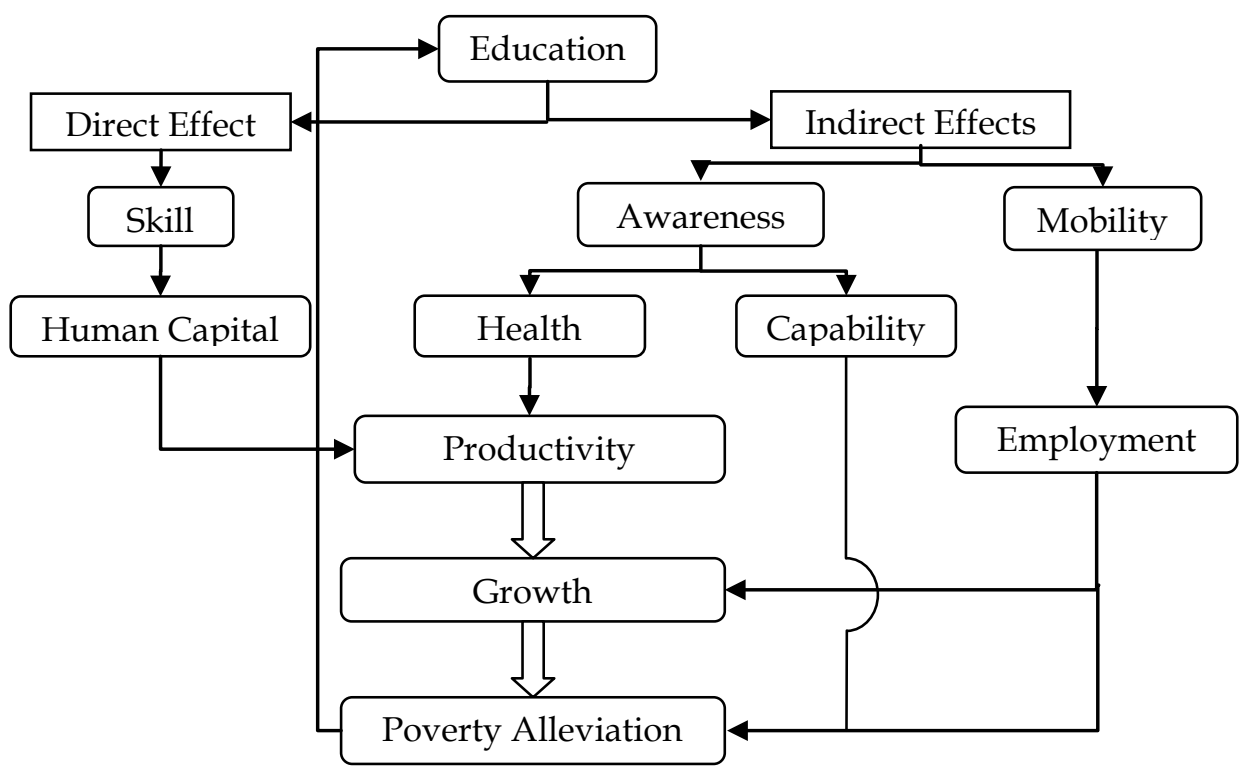

From another but similar point of view, education pays off through both private and social returns. The distinction between private and social returns to education is that private returns refer to benefits received by the individual who acquires additional schooling, and social returns refer to benefits gained by society from that individual's schooling. Private returns include economic benefits such as higher lifetime earnings, lower levels of unemployment, and greater job satisfaction. They can also include consequences such as improved health and longevity. According to the human capital theory, schooling raises earnings because it enhances workers' skills, thus making employees 
more productive and more valuable to employers. Riddell (2004) holds that the strong positive relationship between education and earnings is one of the most well established relationships in the social sciences.

Figure 3: Private and Social Returns of Education

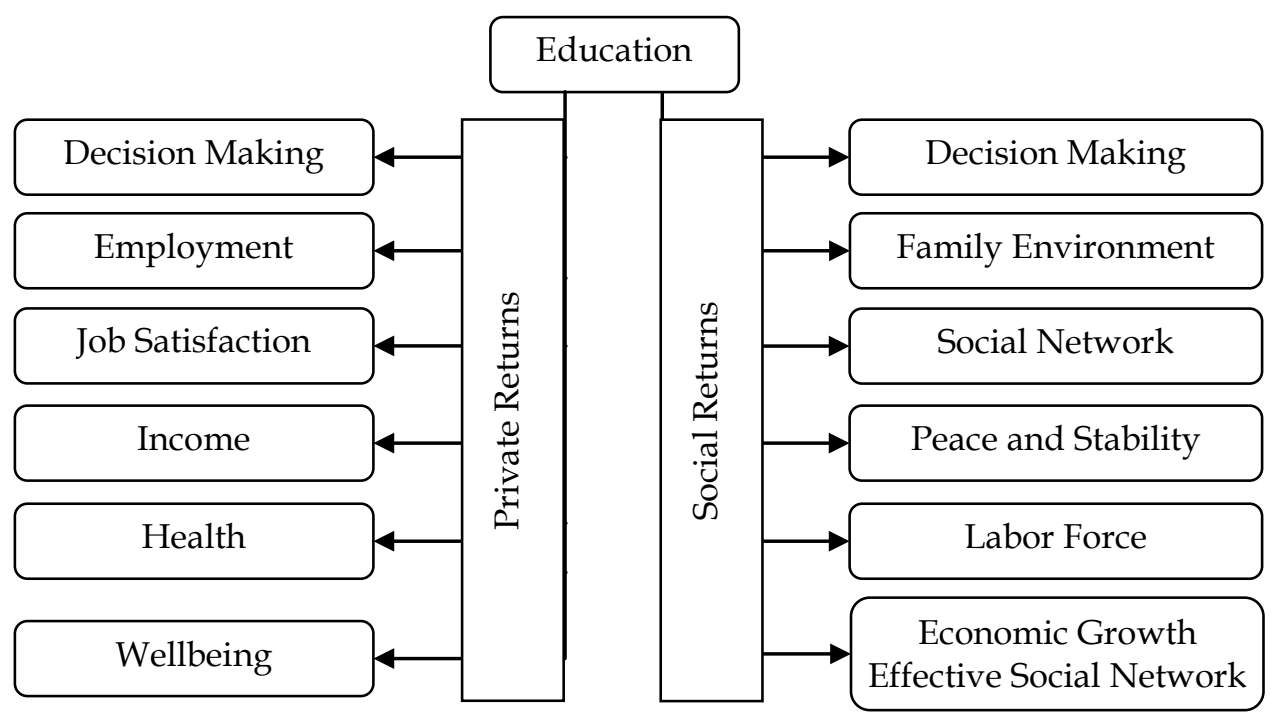

The above mentioned literature proposes that education can reduce poverty through direct (income) and indirect (externalities) channels. In poverty reduction policymaking, an important choice is the level of education. Based on labor requirements and a country's development level, Gemmel (1996) finds that primary education is the most important for economic growth in low-income developing countries, secondary education for middle-income developing countries, and tertiary education for rich countries.

Self and Grabowski (2004) examine the impact of different educational levels on income in India. They classify education into three levels: primary, secondary, and tertiary. Their results show that primary education has a strong positive causal impact on income growth while secondary education has a comparatively limited impact on income growth.

Verner (2004) reveals that breaking the inter-generational transmission of poverty requires extensive action in the education sector. Low-quality education leads to low income, which in turn perpetuates poverty. He concludes that educational attainment is the single most important poverty-reducing factor. All levels of education from primary to tertiary are significant and negatively associated with the probability of 
being poor. He suggests that improvements in access to and quality of education have been key to poverty reduction in Paraíba and northeast Brazil.

Previously, most studies on education showed that primary education yielded the highest returns but recent studies reveal mixed results in favor of both primary and secondary education. This indicates that the returns to education vary from country to country with factors such as the level of development, supply of educated workers, and shifts in the demand for skilled workers in the development process.

The literature review leads us to three conclusions. First, education can increase an individual's earnings by enhancing productivity and thus can significantly help reduce poverty. Second, the impact of education on poverty does not work only via income or a productivity mechanism (direct impact) but also through a number of externalities (indirect impact), e.g., through reduced infant mortality, better decisions, improved health and parental education, etc. Third, the impact of education on poverty can vary across regions due to a number of factors including economic circumstances, labor market requirements and the level and quality of education. These three conclusions suggest that education is a key variable in poverty alleviation. Thus, there is space for a study at the macroeconomic level to estimate the relationship between education and poverty due to the former's wide and unambiguous range of impacts on the latter.

\section{Methodology of Investigation}

This section defines the relevant variables and structure of our econometric model. The variables used in this study are poverty, per capita income, income inequality, and education.

\subsection{Definitions of Variables}

There is no commonly agreed definition of poverty. Definitions differ on what are to be considered basic human needs. However, the central meaning of poverty in all these definitions revolves around the "lack of fulfillment of basic needs." Poverty has many dimensions: for some, it is purely an economic matter; for others, it has social aspects too. Even within the economic notion, the ideas of absolute and relative poverty exist. This applies equally to the social point of view where there are further subcategories, e.g., political and psychological. In using different meanings and concepts of poverty, we are likely to come across 
diverse methods of calculating poverty, resulting in dissimilar estimates. It is very difficult to quantify a social aspect of poverty for measurement purposes, which is why economic measures of poverty are often used in empirical research. Economic poverty is measured in both absolute and relative terms. For both measures, poverty can be defined as the inability to afford an adequate level of consumption, where this adequate level of consumption is defined as the bare minimum in the former and as an average in the latter (Black, 2003). Here, we use the definition of absolute poverty for the purpose of estimation. The questions why and which poverty measure we will use are explained in the next section.

The most comprehensive meaning of income in the literature is: "the amount of goods and services received by an individual" (Black, 2003). At the aggregate level, GDP refers to domestic income and gross national product (GNP) to national income. People are considered poor when they do not have enough income to fulfill their basic needs. An individual's income plays a key role in his/her poverty status when we consider the economic measure of poverty (either absolute or relative) because in both approaches the premise behind the measurement is income (expenditure). We can say that the same holds for a country's GDP/GNP per capita at the aggregate level with regard to its poverty rank. Pro-growth activists are of the view that an increase in the per capita income of a country ultimately leads to a decrease in the number of poor by increasing individuals' incomes or vice versa. It is a familiar notion in the literature that higher growth rates of per capita income convert into poverty reduction (Goh et al., 2009; Besley \& Burgess, 2003). Generally, the growth rate of per capita income has been given a central objective status in poverty reduction programs throughout the world. However, countries experience poverty reduction through economic growth focused on the productive use of labor, the only asset owned by the poor (Squire, 1993). This finding makes it clear that pro-poor growth helps reduce poverty.

Income distribution has been widely discussed in the economic literature. Classical economists analyzed the distribution of income between factors of production. Recent economic literature on income distribution focuses primarily on individuals and households. By definition, income distribution refers to how the total income of a country is distributed among its population. The Lorenz curve and Gini coefficient (both measures of income distribution) represent the overall structure of income distribution among the population. The Gini coefficient indicates the level of income inequality by using the income 
shares of the bottom and top quintiles of the population. The value of the Gini coefficient ranges between 0 and 1, where 0 indicates perfectly equal and 1 perfectly unequal income distribution. When the Gini coefficient is 0 , all individuals in a society have the same income; when the Gini coefficient is 1 , only one person has the whole income. Thus, the higher the value of the Gini coefficient, the greater is the degree of income inequality in a society. It has been argued that a more unequal distribution (income inequality) will ultimately push low-income people into poverty. The underlying idea is that if a few people share a very small part of the national income compared to others, then the poverty risk is greater for them. A number of empirical studies have verified this positive relationship between income inequality and poverty (Besley \& Burgess, 2003; Goh et al., 2009).

Education means acquiring knowledge. Formal education, usually known as schooling, is the process of transferring knowledge and skills from one generation to the next. The education process can be divided into a number of stages, starting from basic literacy and numeracy to specialist learning. An individual's earning ability depends on his/her IQ, education, skills, and access to earning opportunities. Earnings or returns on education can take the shape of services, goods, or financial means. The volume of returns on education depends on the nature and quality of required skills and knowledge.

The stock of people with knowledge and skills is commonly known as human capital, and the basic source for acquisition of human capital is formal education. Some studies argue that the economic role of education or human capital is to foster economic growth by increasing per capita income. Empirical study-based results support the view that the higher a country's stock of human capital, the higher will be the income growth rate. On the other hand, various studies also support the view that formal education (schooling) does not lie solely behind economic growth but that other factors (physical capital accumulation, foreign trade, and the spread of financial services) also promote economic growth (Mitch, 2005). This view does not reject the idea that education helps people earn a higher income. Different rates of return for different schooling levels have been calculated throughout the world. These rates 
vary from region to region depending on various factors. Thus, education can cause distributional changes in the income patterns of an economy. ${ }^{3}$

\subsection{Variables and Model}

Absolute and relative measures of poverty vary across countries. Relative poverty cannot be used as a measure of comparison between countries because they lack equivalent baselines. Different countries apply different poverty lines to measure absolute poverty but this difference exists only at currency levels. The basic concept behind absolute poverty measures is "command over commodities" and these commodities are similar in all surveys as supervised by the World Bank. For cross-country analysis, the same reference poverty line will produce better results at the aggregate level. Using PPP exchange rates based on the 1993 consumer price indexes (CPIs) of the countries studied, Chen and Ravallion (2001) constructed a poverty line of US\$1.08 per day/person, known as the "Dollar a Day" poverty line. A revised version of the poverty line using CPI data for 2005 has also been developed, which indicates US\$1.25 per day/person. ${ }^{4}$ This poverty line reveals what percentage of the population is poor at a given point in time. This common headcount method is based on individuals' income/expenditure and both are commonly used to measure absolute poverty. The headcount of people living below the poverty line is denoted by $\mathrm{P}$ in our study.

Growth at the country level is usually measured in terms of GDP or GNP, so higher growth means higher income and vice versa. However, we also know that the poverty headcount measure calculates the national individuals living below the poverty line. Thus, in relation to poverty, it is preferable to use GNP statistics rather than GDP as it also works via the concept of national product. Another rationale for using GNP is that it includes income earned abroad by a country's citizens and a bulk of this income comes to the country in the form of remittances: many poor households live on the income sent from abroad by other household members. If we compare growth in absolute and per capita GNP, we find that per capita GNP growth is a better measure for poverty estimation than absolute GNP growth as it includes the population effect.

\footnotetext{
${ }^{3}$ In his introduction to the Wealth of Nations, Adam Smith (1776, p. 1) states that the proportion between the annual produce of a nation and the number of people who are to consume that produce depends on "the skill, dexterity, and judgment with which its labour is generally applied."

${ }^{4}$ Data for both poverty lines was taken from the International Comparison Program.
} 
Income inequality is another commonly used variable as a determinant of poverty in cross-country studies. ${ }^{5}$ There are different ways to measure income distribution: the Hoover index, Theil index, and Gini index measure income inequality. The Gini index is the most frequently used inequality index in empirical studies because it satisfies four important principles: anonymity, scale independence, population independence, and transfer principle. Besley and Burgess (2003) state that "although Gini coefficient is a one dimensional measure of distribution and even such measures can miss important changes in income distribution, it represents the only means of looking at the relationship between inequality and poverty for a broad range of countries." In line with Besley and Burgess (2003), we construct the following model to estimate poverty:

$$
\mathrm{P}_{i}=\alpha_{0}+\alpha_{1} \text { PIncome }_{i}+\alpha_{2} \text { Gini }_{i}+\varepsilon
$$

$\mathrm{P}$ is the headcount of people (as a percentage of population) living below the poverty line of the $i$ th country where $i$ represents the crosssection units and PIncome denotes the per capita income growth of the $i$ th country. In Equation (1) $\alpha_{0}$ is the intercept term, $\alpha_{1}$ is an estimate of the effectiveness of per capita income growth on poverty, and $\varepsilon$ is the error term. Most of the existing literature suggests that a country's income growth affects its poverty magnitude in the opposite direction, which means that, if income growth is positive, it will reduce the poverty headcount and vice versa. Thus, the expected sign for $\alpha_{1}$ is negative. An appealing implication of doubts regarding the "trickle down" theory is that the expected negative relationship between poverty and per capita income might still exist but its robustness is likely to be low. ${ }^{6}$ In Equation (1), Gini represents the level of income inequality in the $i$ th country and $\alpha_{2}$ is a parameter that estimates the extent to which poverty is driven by income inequality. Most of the evidence from the literature supports a positive relationship between income inequality and poverty, so the sign for $\alpha_{2}$ is expected to be positive. This positive relationship implies that the

\footnotetext{
${ }^{5}$ The asset inequality variable can also affect a country's poverty level. However, the ratio of asset rich-income poor people is very low compared to income rich-asset poor people. Therefore, the income inequality measure fulfils the requirement of the inequality variable. Another problem of correlation between both inequality variables can arise when we use both variables in the same regression estimation.

${ }^{6}$ This expected low robustness of income growth can be deemed as an opposition to the "trickle down” proposition.
} 
poverty headcount and income inequality will move in the same direction where poverty is stimulated by income inequality. ${ }^{7}$

Sources of education vary between informal sources (e.g., libraries, the Internet, and museums) and formal sources (e.g., schooling and institutional training). The number of people in a country who undergo schooling is usually much higher than the number of people who have gone through training and gross and net enrolment rates are common measures that denote the number of students enrolled in school. Both enrolment rates are widely used as a measure of education in countrylevel investigations. The net enrolment rate is the more appropriate way of gauging how many people go through formal education in a country. The advantage of using the net enrolment rate over the gross enrolment rate is that the former does not overstate the numbers as in the case of the latter due to repeaters and replacements. Although the literacy rate is also a measure of education, the definition of the literacy rate ${ }^{8}$ proposes that literacy alone will not help a person earn enough income to meet his/her essential expenditures. Formal education measures provide suitable datasets for this purpose.

In Equation (2), NES represents the net enrolment rate for formal secondary education in the $i$ th country and $\alpha_{3}$ is a measure of its effectiveness on poverty.

$$
\mathrm{P}_{i}=\alpha_{0}+\alpha_{1} \text { PIncome }_{i}+\alpha_{2} \text { Gini }_{i}+\alpha_{3} \text { NES }_{i}+\varepsilon
$$

In the above equation, $\alpha_{3}$ is a parameter of the relationship between education and poverty. Based on our earlier discussion, the expected sign for parameter $\alpha_{3}$ for education is negative. The enrolment rate for secondary education is a commonly used proxy variable for education. Secondary education seems to have a stronger effect on poverty alleviation. 9 Equation (2) could be estimated if we needed coefficients at one point in time for all three hypotheses (see Section-1). However, our dataset comprises both cross-section as well as time series components. After the addition of the time series representative term $t$, the model is given in the following equation:

\footnotetext{
${ }^{7}$ Ravallion and Chen (1997) also show that growth in average living standards is almost uncorrelated with income distribution.

${ }^{8}$ The literacy rate indicates the proportion and number of persons within the population who can both read and write a short simple statement on their everyday life with understanding (http://data.un.org/).

${ }^{9}$ Professional (vocational and technical) education can effectively contribute to improving human capital. However, due to the nonavailability of data, it is not included in our estimation.
} 


$$
\mathrm{P}_{i t}=\alpha_{0}+\alpha_{1} \text { PIncome }_{i t}+\alpha_{2} \text { Gini }_{i t}+\alpha_{3} \text { NES }_{i(t-1)}+\varepsilon
$$

\section{Data Analysis and Results}

In this section, we discuss data, estimation technique, and our estimation results.

\subsection{Sources and Compilation of Data}

Data for the poverty headcounts and Gini coefficients was downloaded from the World Bank's online PovcalNet. ${ }^{10}$ Data for per capita income and net enrolment rates was taken from a UN data source. ${ }^{11}$ Data for each variable was taken from the same source across the time series as well as cross-section units because different data sources may have used different techniques and tools for data collection. Moreover, the maximum available data for both time series and crosssection units was collected to minimize the artificial effect of interpolation or extrapolation. Apart from these precautionary measures, specific steps were taken in collecting data for each variable. For the poverty headcount, a revised version of the poverty line (US\$1.25 per day/person at PPP 2005) was used. The UN data source was used to collect figures for net enrolment rates because UNESCO had collected this data by standardizing the years of education at the secondary level, which is advantageous for a cross-country comparison.

A dataset with a total population of 51 countries met the above mentioned required criteria. Our dataset constitutes a sample of 40 countries as cross-section units and nine years as time series units for each cross-section unit starting from 1999 to 2007 (see Appendix-1). Data for the poverty headcount $(\mathrm{P})$ and Gini coefficient (Gini) was available at a frequency of three years in 1999, 2002, and 2005. For the variable of per capita income growth (PIncome), there were no missing values. The UN data source lacked enrolment rates at the secondary level for a few countries, among which only one or two time series units of data were missing for secondary net enrolments. In no case was any country selected that had more than four missing data points in the complete time series of any variable.

\footnotetext{
${ }^{10}$ Retrieved from http://iresearch.worldbank.org/PovcalNet/povcalSvy.html

${ }^{11}$ Retrieved from http://data.un.org/
} 


\subsection{Method of Estimation}

In this study, we have used poverty as a dependent variable, and income, income inequality, and education as independent variables in Equation (3). Our data constitutes both cross-section and time series statistics and thus longitudinal data, or panel data, and has various advantages (Gujarati, 2005, p. 638; Dougherty, 2007, p. 409). First, it provides a better chance of studying the dynamics of change due to its larger sample size. Second, due to the combination of cross-section and time series units, it captures both spatial and temporal dimensions. Third, it can effectively capture the complexity of human behavior. Fourth, it may offer a solution to the problem of unobserved heterogeneity.

The two well-known techniques used for panel data in the GLS method are the fixed effect method (FEM) and random effect method (REM). FEM is appropriate in situations where the individual-specific intercept might be correlated with one or more regressors. A disadvantage of this method is that it consumes a lot of degrees of freedom when the number of cross-sectional units is large as more dummy variables are required (Yafee, 2003). Another major disadvantage (also in our case) of FEM is that "time-invariant variables and slowly moving variables can produce high standard errors or insignificant results" (Wilson \& Butler, 2007), whereas REM assumes that the intercept of an individual unit is a random error from a mean value. Due to this assumption, REM requires a randomly selected sample from a given population. It is appropriate in a situation where the intercept of each cross-sectional unit is uncorrelated with the regressors. One advantage of REM over FEM is that it uses fewer degrees of freedom. Moreover, slow-moving or time-invariant variables can also be included while applying REM in contrast to FEM (Yafee, 2003).

The literature suggests that, if a sample is nonrandom, we should use FEM; if the sample is random, then the Hausman test will provide decisive indication regarding a suitable method (Dougherty, 2007, p. 421; Wooldridge, 2002, p. 288; Baltagi, 2005, p. 66). Given the above aspects, we will use REM followed by the Hausman test as our sample is drawn from a larger population of countries and the problem of greater degrees of freedom can also be avoided. Thus, the final equation for estimation is:

$$
\mathrm{P}_{i t}=\alpha_{0}+\alpha_{1} \text { PIncome }_{i t}+\alpha_{2} \text { Gini }_{i t}+\alpha_{3} \text { NES }_{i(t-1)}+\mu_{i t}
$$

The error term $\mu_{i t}$ consists of both errors: the error from the intercept term and the error from the regressors. 


\subsection{Estimation and Results}

Table-1 shows the regression estimates of coefficients for the whole dataset and for different subsets. Here, we have presented selected statistics for both individual variables and the overall model.12

Table-1: Selected Estimation Results

\begin{tabular}{lccccc}
\hline Estimation Method & FEM & REM & REM & REM & REM \\
\hline Variable & $\begin{array}{c}\text { Set 1 } \\
\text { Coefficient } \\
\text { (p-value) }\end{array}$ & $\begin{array}{c}\text { Set 2 } \\
\text { Coefficient } \\
\text { (p-value) }\end{array}$ & $\begin{array}{c}\text { Set 3 } \\
\text { Coefficient } \\
\text { (p-value) }\end{array}$ & $\begin{array}{c}\text { Set 4 } \\
\text { Coefficient } \\
\text { (p-value) }\end{array}$ & $\begin{array}{c}\text { Set 5 } \\
\text { Coefficient } \\
\text { (p-value) }\end{array}$ \\
\hline Per capita income & -0.15145 & -0.2365 & -0.2379 & -0.0387 & -0.3985 \\
growth & $(0.0002)$ & $(0.0268)$ & $(0.0005)$ & $(0.0538)$ & \multicolumn{1}{c}{$0.0000)$} \\
Income inequality & 0.204628 & 0.5263 & 0.0937 & 0.4948 & -0.0540 \\
Net enrollment rate & $(0.3291)$ & $(0.2866)$ & $(0.6669)$ & $(0.0021)$ & $(0.8585)$ \\
in secondary & -0.23682 & -0.5078 & -0.2881 & -0.1236 & -0.4662 \\
education & $(0.0476)$ & $(0.0211)$ & $(0.0202)$ & $(0.1170)$ & $(0.0002)$ \\
Adjusted R2 & & & & & 0.4956 \\
\hline
\end{tabular}

Notes: * Set 1 consists of the whole sample of 40 countries.

* Set 2 consists of 12 low-income countries.

* Set 3 consists of 16 lower middle-income countries.

* Set 4 consists of 12 upper middle-income countries.

* Set 5 consists of 12 countries that experienced high rates of poverty reduction during the observed period.

The table shows that PIncome is inversely related to the poverty headcount for the whole dataset. The p-value shows that the coefficient of PIncome is significant. Although the sign carried by the coefficient of PIncome favors the view that growth in per capita income reduces poverty, the coefficient's magnitude shows that per capita income growth has a moderate influence in terms of poverty reduction compared to other variables. The Gini coefficient shows that income inequality does not play a role in poverty reduction when compared to PIncome because it is not statistically significant. We also observe that the education-related coefficient is dominant compared to other coefficients in terms of magnitude and also strongly significant as shown by the p-values. The

${ }^{12}$ A lower p-value under the Hausman test suggests that FEM is a more suitable method for estimation than REM (see Appendix-2). Therefore, we have used FEM for estimation of the whole dataset (for REM results, see Appendixes-4 and 5). However, for all subsets, the results of the Hausman test favored the use of REM. For summery statistics, see Appendix-3. 
bottom row shows the overall significance of the estimated model where $\mathrm{R}^{2}$ is almost 0.96 and its p-value indicates that it is statistically significant. The following figures illustrate regression lines for each variable against the poverty headcount.

Figure-2: Relationship between Poverty and Independent Variables (Whole Sample)
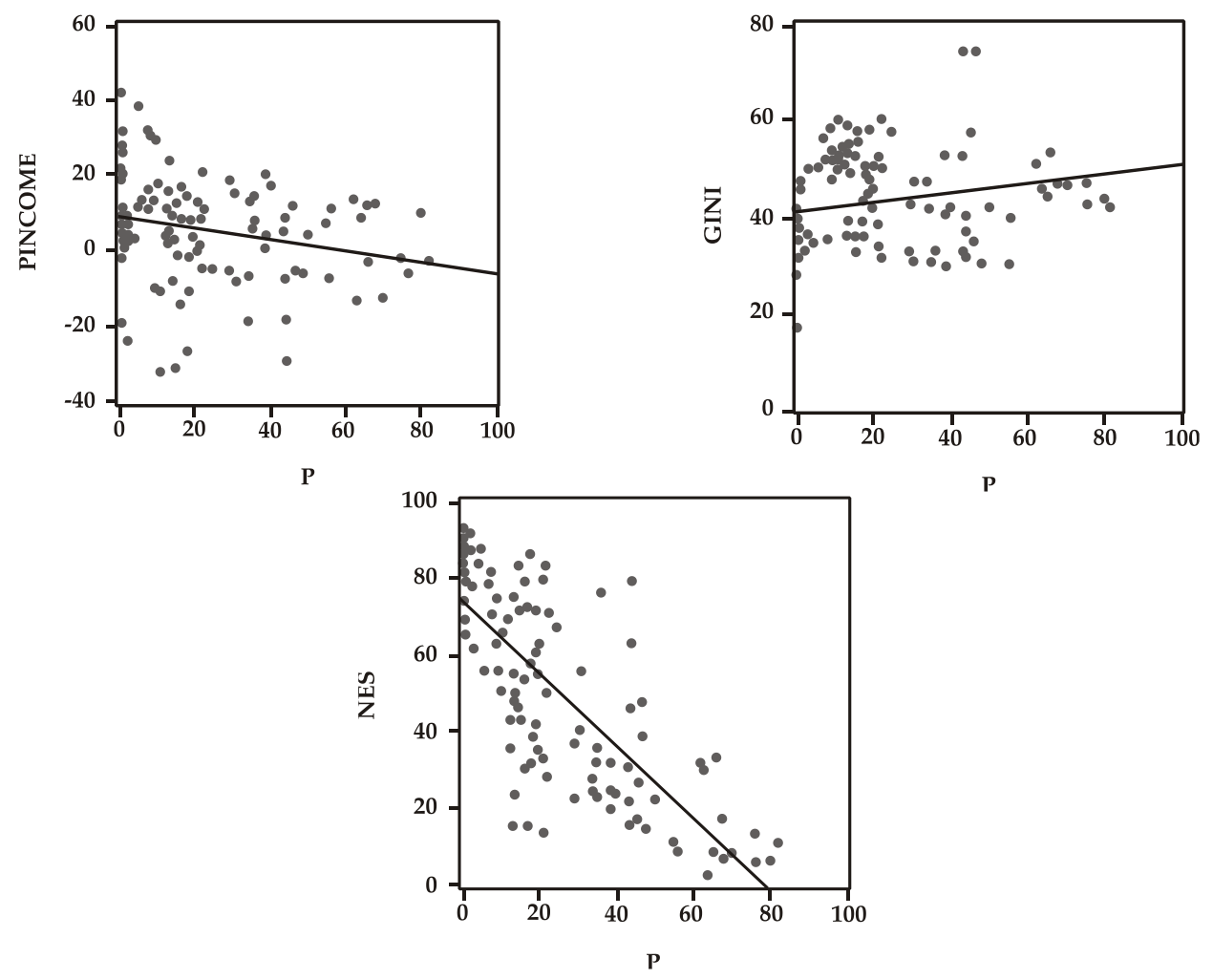

The upper right figure shows a positive relationship between income inequality and poverty, but the relationship is not statistically significant. The upper left and lower figures show a negative relationship between per capita income growth and education and poverty. However, the lower figure's steeper slope indicates a strong negative relationship between education and poverty as compared to the modest negative relationship between per capita income and poverty as shown in the upper left figure.

For our first hypothesis, our derived results from the whole sample favored the view that formal education has a robust and significant effect on the poverty status of the sample countries. Thereafter, we divided our selected countries into three different income groups (low 
income, lower middle income, and upper middle income) and estimated the same model for all three groups.

In the low-income group, the relationship between per capita income and poverty is significant. The relationship between income inequality and poverty is not significant, while that between education and poverty alleviation is more significant than the result of the total sample.

In the case of lower middle-income countries, the magnitude of the relationship between per capita income and poverty is similar to that of low-income countries. The Gini coefficient appears to be insignificant, while the coefficient for secondary education remains significant but with a moderately reduced magnitude.

In the upper middle-income group, the PIncome and Gini coefficients are significant. This is the only group of countries in which income inequality significantly affects poverty. The magnitude of the Gini coefficient shows that, when per capita income is high, income inequality can play a key role in poverty incidence. The secondary education-related coefficient loses its significance in this group of countries.

We selected 12 countries from the total dataset that had experienced high rates of poverty reduction between 1999 and 2007 to determine the determinants of poverty alleviation. Interestingly, our estimates show that per capita income and education are both statistically significant and their magnitudes show that both have a strong effect on poverty in this group. However, the coefficient for income inequality is not significant.

\section{Conclusion and Recommendations}

The above estimates drawn from the whole dataset lead us to three conclusions. First, per capita income growth played a moderate role in poverty alleviation in our selected countries during the observed period. Second, a decrease in income inequality played a stronger role in poverty reduction only in countries with higher per capita incomes. Third, secondary education emerged as the main contributor to poverty alleviation.

As discussed earlier, education clearly enhances people's earning ability. Interestingly, education can also help reduce poverty even if there is low growth in overall per capita income and little change in a country's income inequality. For example, as most illiterate people in developing 
countries are poor, a policy pursuing a more educated population will lead to an increased supply of skilled labor in the economy, which will tend to decrease the wage rate, inducing increased demand for skilled labor. Due to the increased income of the poor, even with low income growth and little improvement in income distribution, the poor can be uplifted in a sustainable way, whereas mere income supports or subsidies will only help them for a shorter period. This is the difference between "enabling people" and "making people capable."

Keeping in view the above mentioned conclusions, economic policymaking in developing countries, without neglecting income growth and income distribution, should focus primarily on promoting education. At the same time, countries with comparatively higher per capita incomes should focus more on the distribution of income to achieve their objective of poverty eradication. 


\section{References}

Anand, S., \& Ravallion, M. (1993). Human Development in Poor Countries: On the role of Private Incomes and Public Services. Journal of Economic Perspectives, 7(1), 133-150.

Baltagi, B. H. (2005). Econometric Analysis of Panel Data (3rd Ed.). West Sussex, UK: John Wiley \& Sons.

Banerjee, A.V., and Newman, A.F. (1994). Poverty, Incentives, and Development. American Economic Review, 84(2), 211-215.

Barro, R.J. (1996). Determinants of Economic Growth: A Cross-Country Empirical Study (Working Paper 5698). Cambridge, MA: National Bureau of Economic Research.

Bénabou, R. (2003). Human Capital, Technical Change, and the Welfare State. Journal of the European Economic Association, 1(2/3), 522-532.

Berg, S. van der. (2008). Poverty and Education. Paris: International Institute for Educational Planning and International Academy of Education.

Besley, T., and Burgess, R. (2003). Halving Global Poverty. Journal of Economic Perspectives, 17(3), 3-22.

Black, J. (2003). A Dictionary of Economics. Oxford: Oxford University Press.

Canagarajah, S., Mazumdar, D., and Ye, X. (1998). The Structure and Determinants of Inequality and Poverty Reduction in Ghana, 1988-92 (Policy Research Working Paper). Washington, DC: World Bank.

Chen, S., and Ravallion, M. (2007). Absolute Poverty Measures for the Developing World, 1981-2004. Proceedings of the National Academy of Sciences, 104(43), 16757-16762.

Chronic Poverty Research Centre, (2005). The Chronic Poverty Report 20042005. Manchester, UK: Author.

Chronic Poverty Research Centre. (2008). The Chronic Poverty Report 200809. Manchester, UK: Author. 
Datt, G., and Ravallion, M. (1998). Why have some Indian States done better than others at Reducing Rural Poverty? Economica, 65(257), 17-38.

Dollar, D., and Kraay, A. (2004). Trade, Growth, and Poverty. Economic Journal, 114(493).

Dougherty, C. (2007). Introduction to Econometrics. Oxford University Press.

Easterly, W., and Levine, R. (2000). It's not Factor Accumulation: Stylized Facts and Growth Models (draft for Policy Research Group). Washington, DC: World Bank.

Ellis, G.F.R. (1984). The Dimensions of Poverty. Social Indicators Research, 15(3), 229-253.

Fafchamps, M., and Quisumbing, A.R. (1999). Human Capital, Productivity, and Labor Allocation in Rural Pakistan. Journal of Human Resources, 34(2), 369-406.

Feldstein, M. (1998). Income Inequality and Poverty. (Working Paper 6770). Cambridge, MA: National Bureau of Economic Research.

Geda, A., Jong, N. de, Kimenyi, M.S., and Mwabu, G. (2005). Determinants of Poverty in Kenya: A Household Level Analysis. Working Paper 2005-44, Storrs, CT: University of Connecticut.

Gemmell, N. (1996). Evaluating the Impacts of Human Capital Stocks and Accumulation on Economic Growth: Some New Evidence. Oxford Bulletin of Economics and Statistics, 58(1), 9-28.

Goh, C., Luo, X., and Zhu, N. (2009). Income Growth, Inequality and Poverty Reduction: A Case Study of Eight Provinces in China. China Economic Review, 20(3), 485-496.

Gujarati, D. N. (2005). Basic Econometrics. New York, NY: McGraw-Hill.

Gundlach, E., Pablo, J.N. de, and Weisert, N. (2002). Education is Good for the Poor: A Note on Dollar and Kraay (2001). Helsinki: World Institute for Development Economics Research. 
Harper, C., Marcus, R., and Moore, K. (2003). Enduring Poverty and the Conditions of Childhood: Lifecourse and Intergenerational Poverty Transmissions. World Development, 31(3), 535-554.

Krueger, A., and Lindahl, M. (2001). Education for Growth: Why and for Whom? Journal of Economic Literature, 39, 1101-1136.

Londoño, J. L. (1996). Poverty, Inequality, and Human Capital Development in Latin America, 1950-2025 (World Bank Latin American and Caribbean Studies: Viewpoints). Washington, DC: World Bank.

Maitra, P. (2000). The Effect of Household Characteristics on Poverty and Living Standards in South Africa. doi: 10.2139/ssrn.241109

Mitch, D. (2005). Education and Economic Growth in Historical Perspective. In R. Whaples (Ed.), EH.Net Encyclopedia.

Orazem, P., Glewwe, P., and Patrinos, H. (2007). The Benefits and Costs of Alternative Strategies to Improve Educational Outcomes. Working Paper 07028, Ames, IA: Iowa State University.

Ravallion, M. (2001). Comment on "Counting the World's Poor" by Angus Deaton. World Bank Research Observer, 16(2), 149-156.

Ravallion, M. (2003). The Debate on Globalization, Poverty and Inequality: Why Measurement Matters. International Affairs, 79(4), 739-753.

Ravallion, M., and Chen, S. (1997). What can New Survey Data tell us about Recent Changes in Distribution and Poverty? World Bank Economic Review, 11(2), 357-382.

Ravallion, M., and Datt, G. (1996). How Important to India's Poor is the Sectoral Composition of Economic Growth? World Bank Economic Review, 10(1), 1-25.

Riddell, W.C. (2004, November). The Social Benefits of Education: New Evidence on an Old Question. Paper presented at the conference "Taking Public Universities Seriously“, University of Toronto.

Rose, P., and Dyer, C. (2008). Chronic Poverty and Education: A Review of the Literature. Working Paper 131, Manchester: Chronic Poverty Research Centre. 
Self, S., and Grabowski, R. (2004). Does Education at all Levels Cause Growth? India, A Case Study. Economics of Education Review, 23(1), 47-55.

Shirazi, N.S. (1994). An Analysis of Pakistan's Poverty and its Alleviation through Infaq. (Unpublished doctoral dissertation). International Islamic University, Islamabad.

Squire, L. (1993). Fighting Poverty. American Economic Review, 83(2), 377382.

United Nations Educational, Scientific and Cultural Organization. (2007). EFA Global Monitoring Report, Strong Foundations: Early Childhood Care and Education. Paris: Author.

Verner, D. (2004). Education and its Poverty-Reducing Effects: The Case of Paraíba, Brazil, Policy Research Working Paper 3321, Washington, DC: World Bank.

Wooldridge, J.M. (2002). Econometric Analysis of Cross Section and Panel Data. Cambridge, MA: MIT Press.

World Bank. (2003). World Development Report 2004: Making Services Work for Poor People. Washington, DC.

World Bank. (2006). World Development Report 2007: Development and the Next Generation. Washington, DC.

World Bank. (2008). World Development Indicators 2008. Washington, DC. 


\section{Appendix-1}

\begin{tabular}{|c|c|c|c|}
\hline No. & ID & Country & Income Group \\
\hline$\overline{1}$ & ALB & Albania & Lower middle \\
\hline 2 & ARM & Armenia* & Lower middle \\
\hline 3 & AZE & Azerbaijan ${ }^{*}$ & Lower middle \\
\hline 4 & BLR & Belarus & Upper middle \\
\hline 5 & $\mathrm{BOL}$ & Bolivia & Lower middle \\
\hline 6 & BRA & Brazil & Upper middle \\
\hline 7 & BGR & Bulgaria & Upper middle \\
\hline 8 & BFA & Burkina Faso* & Low \\
\hline 9 & KHM & Cambodia & Low \\
\hline 10 & $\mathrm{CPV}$ & Cape Verde & Lower middle \\
\hline 11 & $\mathrm{COL}$ & Colombia & Upper middle \\
\hline 12 & ECU & Ecuador & Lower middle \\
\hline 13 & SLV & El Salvador & Lower middle \\
\hline 14 & ETH & Ethiopia* & Low \\
\hline 15 & GMB & Gambia & Low \\
\hline 16 & GHA & Ghana* & Low \\
\hline 17 & GTM & Guatemala & Lower middle \\
\hline 18 & JOR & Jordan & Lower middle \\
\hline 19 & KAZ & Kazakhstan & Upper middle \\
\hline 20 & KEN & Kenya & Low \\
\hline 21 & LPD & Lao People's Democratic Republic ${ }^{*}$ & Low \\
\hline 22 & LSO & Lesotho & Lower middle \\
\hline 23 & MDG & Madagascar ${ }^{*}$ & Low \\
\hline 24 & MYS & Malaysia & Upper middle \\
\hline 25 & MRT & Mauritania* & Low \\
\hline 26 & MEX & Mexico & Upper middle \\
\hline 27 & MNG & Mongolia* & Lower middle \\
\hline 28 & MOZ & Mozambique & Low \\
\hline 29 & NAM & Namibia & Upper middle \\
\hline 30 & NIC & Nicaragua & Lower middle \\
\hline 31 & NER & Niger $^{*}$ & Low \\
\hline 32 & PAK & Pakistan & Lower middle \\
\hline 33 & PER & Peru & Upper middle \\
\hline 34 & POL & Poland & Upper middle \\
\hline 35 & MDA & Republic of Moldova* & Lower middle \\
\hline 36 & LCA & Saint Lucia & Upper middle \\
\hline 37 & SWZ & Swaziland & Lower middle \\
\hline 38 & TJK & Tajikistan ${ }^{*}$ & Low \\
\hline 39 & UKR & Ukraine & Lower middle \\
\hline 40 & VEN & Venezuela & Upper middle \\
\hline
\end{tabular}

Source: World Bank (2009).

* Countries witnessed high rates of poverty reduction during observed period. 
Appendix-2

Hausman specification test

\begin{tabular}{l|c|c}
\hline Chi-sq. Statistics & Chi-sq. d.f. & Prob. \\
\hline 11.22108 & 3 & 0.0106 \\
\hline
\end{tabular}

Appendix-3

Summary statistics

\begin{tabular}{lrrrr}
\hline & \multicolumn{1}{c}{ P } & PIncome & Gini & \multicolumn{1}{c}{ NES } \\
\hline Mean & 24.552 & 5.005 & 43.272 & 51.215 \\
Median & 18.195 & 7.114 & 42.580 & 55.065 \\
Maximum & 82.320 & 42.380 & 74.330 & 92.940 \\
Minimum & 0.000 & -32.165 & 16.830 & 2.660 \\
Std. Dev. & 22.177 & 13.461 & 10.760 & 26.864 \\
Total Obs. & 120.000 & 120.000 & 120.000 & 120.000 \\
\hline & & & & \\
& & & & Appendix-4
\end{tabular}

Regression results using REM

\begin{tabular}{lcccc}
\hline Variable & Coefficient & p-value & Adjusted $\mathbf{R}^{2}$ & p-value \\
\hline PIncome & -0.1134 & 0.0015 & & \\
Gini & 0.1238 & 0.3956 & 0.4364 & 0.0000 \\
NES & -0.5111 & 0.0000 & & \\
\hline
\end{tabular}


Appendix-5

\begin{tabular}{|c|c|c|c|c|c|}
\hline Country & $\begin{array}{c}\text { Fixed Effects } \\
\text { (p-value) }\end{array}$ & Country & $\begin{array}{c}\text { Fixed Effects } \\
\text { (p-value) }\end{array}$ & Country & $\begin{array}{c}\text { Fixed Effects } \\
\text { (p-value) }\end{array}$ \\
\hline Albania & $\begin{array}{l}13.3383 \\
(0.2015)\end{array}$ & Ethiopia & $\begin{array}{l}45.4701 \\
(0.0000)\end{array}$ & Mongolia & $\begin{array}{l}34.0196 \\
(0.0022)\end{array}$ \\
\hline Armenia & $\begin{array}{l}27.7794 \\
(0.0263)\end{array}$ & Gambia & $\begin{array}{l}30.4458 \\
(0.0057)\end{array}$ & Mozambique & $\begin{array}{l}61.5890 \\
(0.0000)\end{array}$ \\
\hline Azerbaijan & $\begin{array}{l}20.8462 \\
(0.0626)\end{array}$ & Ghana & $\begin{array}{l}35.7034 \\
(0.0005)\end{array}$ & Namibia & $\begin{array}{l}40.9546 \\
(0.0146)\end{array}$ \\
\hline Belarus & $\begin{array}{l}15.6663 \\
(0.1819)\end{array}$ & Guatemala & $\begin{array}{l}11.1791 \\
(0.3591)\end{array}$ & Nicaragua & $\begin{array}{l}17.5817 \\
(0.1425)\end{array}$ \\
\hline Bolivia & $\begin{array}{l}26.8509 \\
(0.0730)\end{array}$ & Jordan & $\begin{array}{l}13.0162 \\
(0.2974)\end{array}$ & Niger & $\begin{array}{l}67.5216 \\
(0.0000)\end{array}$ \\
\hline Brazil & $\begin{array}{l}14.4915 \\
(0.3308)\end{array}$ & Kazakhstan & $\begin{array}{l}17.4799 \\
(0.1680)\end{array}$ & Pakistan & $\begin{array}{l}29.7191 \\
(0.0002)\end{array}$ \\
\hline Bulgaria & $\begin{array}{l}16.9641 \\
(0.1627)\end{array}$ & Kenya & $\begin{array}{l}18.8053 \\
(0.0804)\end{array}$ & Peru & $\begin{array}{l}16.2181 \\
(0.2354)\end{array}$ \\
\hline $\begin{array}{l}\text { Burkina } \\
\text { Faso }\end{array}$ & $\begin{array}{l}54.4495 \\
(0.0000)\end{array}$ & $\begin{array}{l}\text { L P D } \\
\text { Republic }\end{array}$ & $\begin{array}{l}43.6236 \\
(0.0000)\end{array}$ & Poland & $\begin{array}{l}15.9550 \\
(0.2190)\end{array}$ \\
\hline Cambodia & $\begin{array}{l}42.9534 \\
(0.0000)\end{array}$ & Lesotho & $\begin{array}{l}35.8491 \\
(0.0031)\end{array}$ & $\begin{array}{l}\text { Republic of } \\
\text { Moldova }\end{array}$ & $\begin{array}{l}34.8216 \\
(0.0054)\end{array}$ \\
\hline $\begin{array}{l}\text { Cape } \\
\text { Verde }\end{array}$ & $\begin{array}{l}24.1466 \\
(0.0544)\end{array}$ & Madagascar & $\begin{array}{l}69.6359 \\
(0.0000)\end{array}$ & Saint Lucia & $\begin{array}{l}26.8051 \\
(0.0256)\end{array}$ \\
\hline Colombia & $\begin{array}{l}17.2905 \\
(0.2180)\end{array}$ & Malaysia & $\begin{array}{c}9.5178 \\
(0.4198)\end{array}$ & Swaziland & $\begin{array}{l}60.7757 \\
(0.0000)\end{array}$ \\
\hline Ecuador & $\begin{array}{l}12.3522 \\
(0.3542)\end{array}$ & Mauritania & $\begin{array}{l}14.4298 \\
(0.0995)\end{array}$ & Tajikistan & $\begin{array}{l}44.6148 \\
(0.0001)\end{array}$ \\
\hline El Salvador & $\begin{array}{l}15.3544 \\
(0.2137)\end{array}$ & Mexico & $\begin{array}{c}9.8816 \\
(0.4347)\end{array}$ & $\begin{array}{l}\text { Ukraine } \\
\text { Venezuela }\end{array}$ & $\begin{array}{l}17.1839 \\
(0.1496) \\
18.0620 \\
(0.1402)\end{array}$ \\
\hline
\end{tabular}

